\title{
Vicarious dissonance and the narrative of the Gospel of Matthew
}

T his article presents a novel social-scientific approach to the Gospel of Matthew, one of the most influential texts in the history of Christianity. This approach combines social-psychological and narrative-critical methodology. The aim is to demonstrate how the gospel narrative functions to transform the social identity of its audience and stimulate group commitment via the social-psychological phenomenon of vicarious cognitive dissonance.

\section{Introduction}

At the very heart of the message of the Gospel of Matthew, there is a call for profound change: 'Renew yourselves, for the kingdom of heaven has come near!' ${ }^{1}$ (Matt. 4:17). Entering the kingdom of heaven requires perfect righteousness (5:20), which seems humanly impossible (19:26). Despite this impossibility, the gospel speaks of 'disciples of the kingdom of heaven' (13:43) and calls all nations to join the community of disciples (28:19). This demanding call has also reached the nations. The Gospel of Matthew became a core scripture of Christianity, which spread rapidly through the Roman Empire, being currently the major religion globally. Certainly, the exceptional dispersion capacity of Christianity cannot be fully explained, but investigating the Gospel of Matthew may reveal at least a shadow of the mystery.

In this article, the identity-transforming rhetoric of the Gospel of Matthew is analysed in light of the

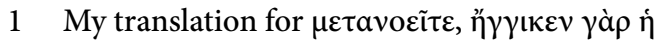
$\beta a \sigma \iota \lambda \varepsilon i \alpha \tau \tilde{\omega} v$ oủ $\rho \alpha v \tilde{\omega} v$. The verb $\mu \varepsilon \tau \alpha v o \varepsilon \dot{\omega} \omega$ includes nuances of meaning: 'perceive afterwards or too late', 'change one's mind or purpose', and 'repent' (Liddell and Scott 1996: 1115). social-psychological theory of cognitive dissonance, and its rather novel extension, vicarious dissonance. Applying the main theory is nothing new in gospel studies, but the application of the extension is. From its beginning, the developers of cognitive dissonance theory have been interested in religious conversion (Festinger et al. 1956). Subsequently the theory began to be applied to gospel studies (Gager 1975). Over time, the theory of cognitive dissonance has gone through significant development (HarmonJones and Mills 1999; Cooper 2007). The notion of vicarious dissonance however is rather novel in cognitive dissonance studies (Norton et al. 2003), and the understanding of vicarious dissonance has been updated recently (Blackman et al. 2016). Therefore, the earlier applications of cognitive dissonance studies to the Gospel of Matthew have not asked similar questions to the ones raised in this study. ${ }^{2}$

In its overall methodology, this article combines the theory of vicarious dissonance with the approach of narrative criticism, which is applied widely in biblical studies and specifically in the study of the Gospel of Matthew (Carter 2015). Applying the theory of vicarious dissonance to the narrative material of Matthew, I will utilise narrative-critical views of the narrative-communication situation to reveal the arousal of vicarious dissonance as a process of communication. I will also focus on the characters

2 Nicholas H. Taylor (1998) offers a review on the previous applications of cognitive dissonance studies in the field of early Christianity, including the gospels, and their criticism. David E. Aune (2013) shows a more recent review and application of cognitive dissonance theory in figuring out the historical origin of the Christian faith. 


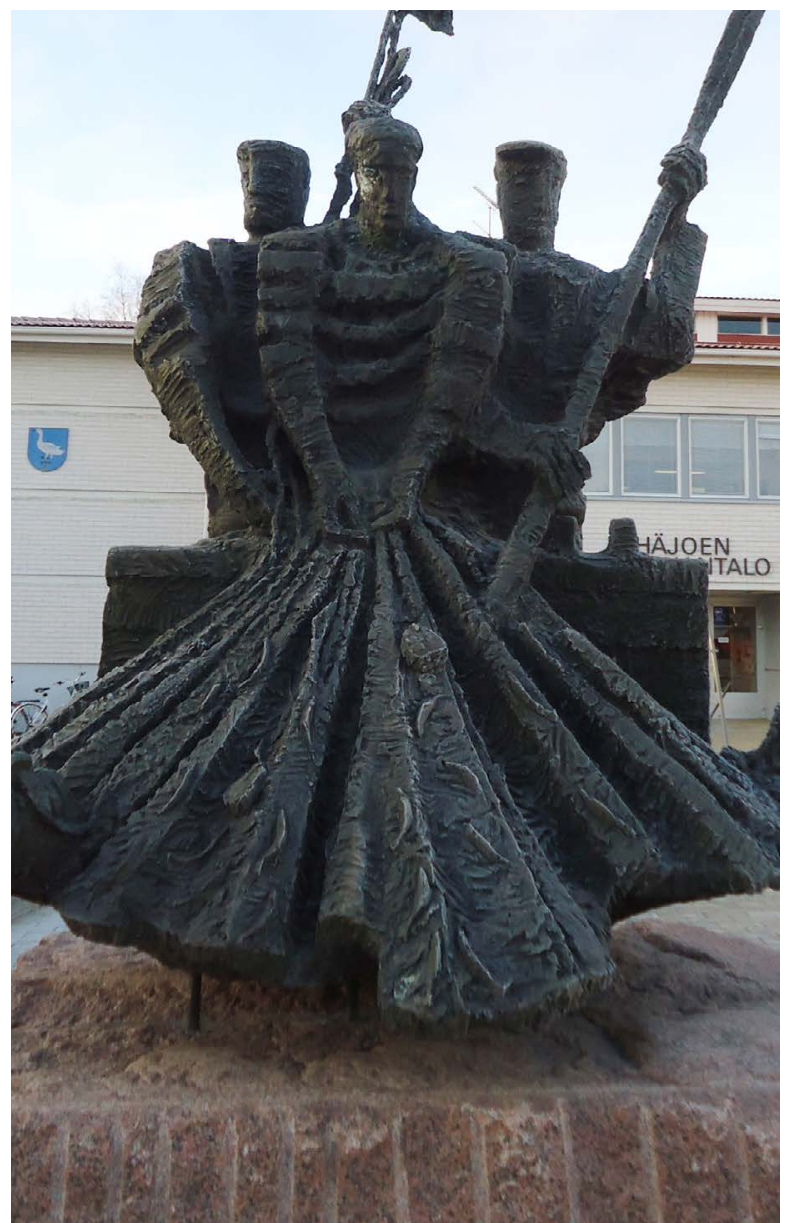

Pauhalla ('On the Shoal', 1987), a sculpture by Kari Juva in front of Pyhäjoki Municipal House. Photo: Anna Karjula.

of the narrative as elements reflecting prototypicality; 'typical or expected properties of a social group' (Smith and Zárate 1992: 4). ${ }^{3}$ Prototypicality has been used as a key term for the experience of shared identity which is required for vicarious dissonance arousal.

The aim of this article is to provide an examination of the dissonance-arousing narrative elements of the Gospel of Matthew. The first part of the article consists of methodological considerations concerning cognitive dissonance and narrative criticism. The second part consists of an analysis of the dissonancearousing traits of the characters of the Gospel of Matthew. The results and implications of the analysis are summed up in the conclusions.

3 Concerning the characterization of the Gospel of Matthew, John Aranda Cabrido (2010) has focused on the character of Jesus in his study. Jeannine $\mathrm{K}$. Brown (2002) has studied the narrative portrayal and function of the Matthean disciples.

\section{Cognitive dissonance and narrative criticism}

The following methodological considerations begin with the basics of cognitive dissonance theory. In the description of the origin and development of the theory I have chosen to focus on the views of Joel Cooper, who has been one of the main theorists of cognitive dissonance for decades. This includes also the development of the vicarious dissonance theory, which is connected with the theory of social identity. As the theoretical basics of vicarious dissonance are described, I will complement them with elements provided by narrative criticism. These are the concept of the narrative-communication situation and the notion of character. With the help of these, I will introduce the concept of dissonance-arousing narrative to provide a background for the subsequent analysis.

\section{Cognitive dissonance and vicarious dissonance}

Presented originally in 1957 by Leon Festinger, the theory of cognitive dissonance concerns the tensions between the cognitions of human beings. Since then, the theory has given much inspiration to social psychology. The main principles of Festinger's theory are as follows (Cooper 2007: 6-9):

- Cognition refers to any psychological representation. It can be knowledge of a behaviour, one's attitude, or the state of the world.

- If a person holds cognitions $\mathrm{A}$ and $\mathrm{B}$ such that $\mathrm{A}$ follows from the opposite of $B$, then $A$ and $B$ are dissonant.

- The holding of two or more inconsistent cognitions arouses the state of cognitive dissonance, which is experienced as uncomfortable tension. This tension has drive-like properties and must be reduced.

- The magnitude of the dissonance is related to the importance of the dissonant cognitions.

- Dissonance can be reduced by revision of some of the dissonant cognitions, typically attitudes, which are more flexible than one's behaviour or the state of the world.

As an example, if one considers giving money to the poor to be important, but happens to ignore a beggar, one may reduce the discomfort caused by these dissonant cognitions by 1 . making a decision to be more generous in the next encounter with a beggar; 2. questioning the beggar's authenticity; 
3. making a decision to donate to an organisation helping the poor instead; or 4. change one's opinion on giving money to the poor (Cooper 2007: 6-8).

Since 1957, cognitive dissonance theory has been developed from Festinger's quite hypothetical considerations into more accurate, empirically-tested models. The state of cognitive dissonance has been recognized as a physiological arousal, and the conditions of dissonance arousal have been defined more accurately. According to the New Look Model of dissonance presented 1984 by Joel Cooper and Russell Fazio:

[I]nconsistent behaviour produces dissonance

- but only when decision of freedom is high

- but only when people are committed to their behaviour

- but only when the behaviour leads to aversive consequences

- but only when those consequences were foreseeable. (Cooper 2007: 73).

The second condition is connected to the third: the potential aversive consequences have to be connected to the social reality outside the laboratory, instead of being theoretical (Cooper 2007: 63). When cognitive dissonance causes physiological arousal, the New Look model shows different ways to relieve the tense state of mind, such as labelling the arousal positively, or attributing it to an external source (ibid. 77-79). In the absence of an obvious external source of discomfort, one attributes the uncomfortable tension to one's own sphere of responsibility and is motivated to change one's attitudes in order to render the consequences of the inconsistent behaviour nonaversive (ibid. 79).

According to the New Look Model, aversive consequences of a behaviour are essential for dissonance arousal, and the motivation to avoid them is the key aspect of dissonance reduction. However, the definition of an aversive consequence depends on the standards of measurement. Aversive consequences are perceived differently depending on the situation, one's self-awareness, self-esteem, values, and the surrounding culture (Cooper 2007: 115-16). The standards of judgment can be based on what a person thinks of him or herself, or on the normative standards of society (ibid. 143). However, the normative standards of society seem to play the decisive role more often (ibid. 115-16). This happens especially in cultures prioritizing interdependence over independence (ibid. 140-7). Cooper writes:

The fact that dissonance is affected differently in different cultures further demonstrates that purely logical inconsistency between cognitive elements is not sufficient to arouse dissonance. Rather, it is the collision of freely chosen behavior with normative and personal standards that give rise to the unpleasant state of dissonance. Behavior that violates normative standards in one culture may be perfectly consistent with normative standards in another. Whether behavior and attitudes are logically consistent or not, dissonance will be aroused only when the behavior violates standards and those, in turn, exist not in a vacuum but in a social context.

(Cooper 2007: 149)

Cognitive dissonance is aroused not only by one's personal behaviour, but also by witnessing the behaviour of those with a common social identity. The theory of social identity, originally presented by Henri Tajfel, sees identity formation as an interaction between personal and group identity (Tajfel 1981: 255). Social identity is based on social categorization, which focuses attention on contextually relevant and meaningful similarities among people, and the differences between them (Hogg 2008: 59). One's social identity is formed through identifying with different groups, to different degrees, and not identifying with others. According to Cooper, shared identity leads to vicarious dissonance, if two other conditions are also met (Cooper 2007: 121):

When I observe someone acting to produce an aversive outcome, I may very well feel his discomfort. This will happen to me if
1. he and I share a social identity caused by our belonging to the same social group;
2. if the group is salient to me at the moment; and
3. if I am attracted to the group.

In addition to belonging to the same social group, the group has to be salient in the situation leading to dissonance arousal. Everyone belongs to several social categories or groups, being not constantly aware of 


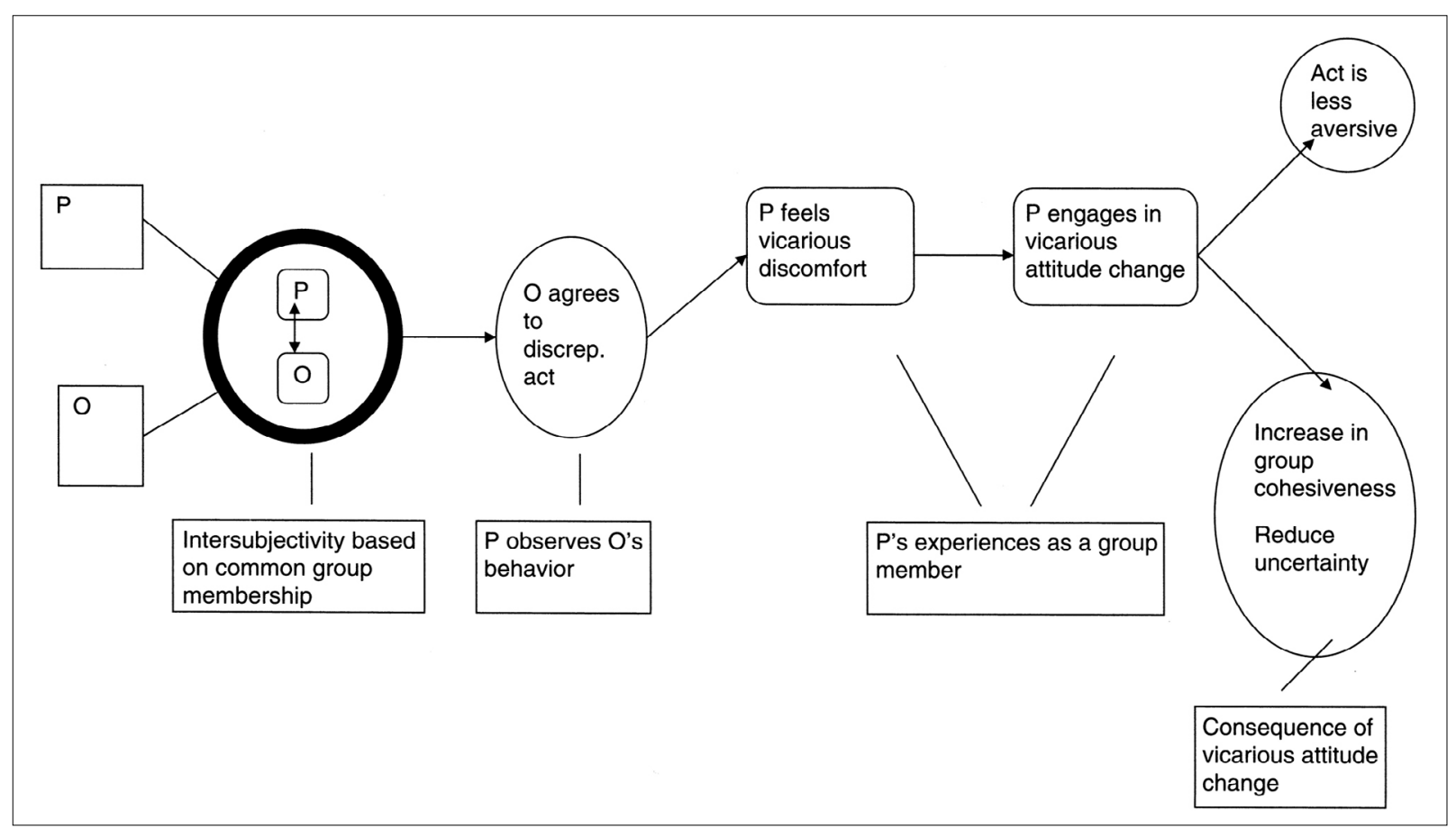

Reprinted from Joel Cooper and Michael A. Hogg's 'Feeling the anguish of others: a theory of vicarious dissonance', p. 382, published in Advances in Experimental Social Psychology vol. 39 in 2007, with permission from Elsevier.

them. The arousal of vicarious dissonance requires awareness of the shared social group, and also attraction towards the group. If one is not attracted to the group one belongs to, vicarious dissonance cannot be observed (Cooper and Hogg 2014: 334).

In contrast to the citation above, vicarious dissonance has more recently been shown not to be about one empathizing with the other and feeling his discomfort, but about one being uncomfortable imagining oneself to be in the same situation as the other. Vicarious dissonance is not aroused by choices that are hard for the actor, but choices that are hard for the observer: 'People process two crucial variables for dissonance arousal - choice and consequences - egocentrically' (Blackman et al. 2016: 6). Even though vicarious dissonance is an egocentric phenomenon, it is aroused by the actions of others. This multiplies the occasions in which cognitive dissonance is experienced and needs to be reduced (Cooper 2007: 117). Joel Cooper and Michael A. Hogg (2007: 382) have presented the process of vicarious dissonance between the participant $\mathrm{P}$ and the person observed, $\mathrm{O}$, as seen in Fig. 1 (above).

The process of vicarious dissonance is very similar to the dissonance caused by personal actions. Also on these occasions, the discomfort can be reduced by a change of attitude (Cooper and Hogg 2007: 377-8).

\section{Narrative criticism and dissonance-arousing narratives}

The occasions arousing vicarious dissonance do not have to be experienced in real time; observing allegedly in-group individuals through texts or recorded audio or video is sufficient for dissonance arousal (Norton et al. 2003; Blackman et al. 2016). I call these texts and recordings of individuals making free choices and acting against their previously expressed attitudes dissonance-arousing narratives. The methodological aim of this article is to observe dissonance-arousing narratives outside the laboratory. Observations like this cannot be done with the accuracy of experimental studies with data surveys and control groups, but may still provide a viable analysis (Cooper 2007: 157).

Outside of an experimental setting, the audience of a dissonance-arousing narrative becomes unrestricted. In this article, the audience is approached with theoretical tools provided by narrative criticism. This approach has been developed within the field of biblical studies, and is akin to the new rhetorical criticism and reader-response movement, as its secular relatives (Powell 1990: 19). According to Mark Allan Powell, 'the goal of narrative criticism is to read the text as the implied reader' (ibid. 18, emphasis mine), which, as the implied reader is an idealized abstraction 'may be somewhat unattainable, but it remains 
a worthy goal nevertheless' (ibid. 21). H. J. Bernard Combrink provides two complementary perspectives on the concept of the implied reader:

Brown (2002: 128) defines the implied reader as a textual construct, constructed from the narrative text, responding appropriately to the text's rhetorical devices and fulfilling the goals of the text. S/he is not limited to a first-time reader and, is also equivalent to what some would call 'the ideal reader'. Besides knowing what has been told in the course of the narrative, the implied reader also has knowledge external to the narrative, including historical and cultural information. (Combrink 2006: 26-7, italics mine)

Warren Carter (2001: 4), who prefers the term 'authorial audience', attempts to define the implied reader slightly more specifically and understands 'the 'authorial audience' to be the receiver, or audience, the author has 'in mind' in writing the text. It is the author's image of the audience being addressed by the text, the image of the audience to whom the gospel writer writes. This image approximates, though it is not the same as, the actual audience. This means that the authorial audience is a 'contextualized implied reader' with the linguistic competence and sociocultural knowledge to read the text appropriately and in a way assumed by the text but not made explicit in it.

Narrative is transmitted in a situation of communication. Seymour Chatman (1979: 151) depicts the whole narrative-communication situation as seen in Fig. 2 (below).

Applying this image to the vicarious dissonance studies mentioned above (Norton et al. 2003; Blackman et al. 2016), the real author is a researcher who has taken part in the writing of the study, and real reader is anyone who has read the study. The authors have not put their whole personality into their writ-

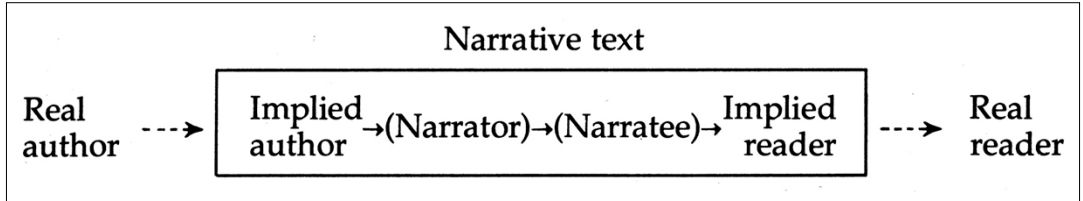

Reprinted by permission of the publisher, Cornell University Press. ing process and just let the stream of consciousness flow: they have only written scientifically valid and relevant facts and thoughts. The implied author is the scientific voice leading the reader through the text, and the real reader is unable to link this narrative voice to an individual real author behind a collaboratively written text. The same applies in the opposite direction: the real authors have not been able to imagine all the potential persons reading the study, but they have been guided by a concept of a scientifically oriented implied reader in their writing process. Inside the narrative, there may or may not be a narrator and a narratee. In the case of these studies, the contributors have written descriptions of their conversations with the participants. In these descriptions the researcher is a narrator and the participant is a narratee. Since one can tell a story about a person telling a story, there may be several levels of narrators and narratees. In a vicarious dissonance study, there is a description of the participants listening to a tape containing a conversation between a researcher and a fictive participant (Norton et al. 2003: 49). In this case, the narrator (researcher) presents the narratee (participant) a conversation between a seconddegree narrator (recorded researcher) and seconddegree narratee (fictive participant).

Applying Fig. 2 to the Gospel of Matthew, the real author is unknown. According to most scholars, the Gospel of Matthew was composed in Syria, most probably in Antioch, in the final quarter of the first century AD (Davies and Allison 2004: 1-147). The real reader is anyone who has read the Gospel of Matthew. The implied author is the overall narrative voice in the text of the Gospel of Matthew. The implied reader is the author's construction, which approximates to the real reader, and can be analysed from the narrative text. Since books, not to mention literacy, were rare in antiquity, copies of the Gospel of Matthew were usually communally owned and read aloud. Thus, the term authorial audience would be a more appropriate term than implied reader. In the text of the Gospel of Matthew, the narrator is usually Jesus. He speaks to various combinations of narratees; for example the high priests and elders in Matt. 21:23-22:14. In this section, there are also second-degree narrators and narratees. In 21:38, the author tells of Jesus describing tenant farmers narrating to each other a vision of dispossessing 
their landlord of his property by killing his inheritor.

In the dissonance-arousing narratives, identifying with the characters in the narrative is a crucial process for the arousal of vicarious dissonance. Powell defines the characters as narrative elements as follows:

Characters are the actors in a story, the ones who carry out the various activities that comprise the plot ... We should not limit our conception of characters to individuals, since it is possible for a group to function as a single character. In our Gospels, this is true not only of the crowds that follow Jesus but also of his disciples and the religious leaders. When the narrative reports that the disciples do something or say something, the reader does not imagine that these 12 individuals actually move or speak in unison. Such stereotyping is a conventional literary device by which a number of characters are made to serve a single role. (Powell 1990: 51)

In the Gospel of Matthew, the implied audience is designed to identify with certain characters and not to identify with others. This is most clearly indicated by the relationship between Jesus and those characters. Jesus is the first, last, and central character in the narrative, the protagonist, and other characters are categorized by their relationship with him.

In terms of social psychology, Jesus is an exemplar representing the essential prototypical traits of his social category. In terms of the Gospel of Matthew, this category could be called children of God (Matt. 5:9, 45). Eliot R. Smith and Michael A. Zárate describe the terms exemplar and prototype as follows:

An exemplar differs from a prototype or schema, both of which are generally taken to involve abstract knowledge about the typical or expected properties of a social group. Exemplars (cognitive representations of individuals) can range from very detailed, complete representations of specific people (my mother or my close friend) to minimal representations involving only two or three attributes. A person need not to be encountered face to face to be represented in memory but may be imagined or experienced through the media or a secondhand account ... (Smith and Zárate 1992: 4)
Joel Cooper and Michael A. Hogg have summarized the significance of the notion of prototype for the vicarious dissonance studies as follows:

In summary, when people identify with a social group, processes unfold that make it likely they will experience what other prototypical group members experience. Because of people's tendency to engage in social categorization and to fuse their individual selves to the group prototype, we suggest that people who witness a fellow group member engaging in dissonanceproducing behaviors will experience dissonance vicariously. And the greater the level of identification an individual has with a group, the greater the level of vicarious dissonance. (Cooper and Hogg 2014: 331)

The notions of prototype and exemplar express the abstract and case-specific sides of social categorization (Hogg 2008: 60). ${ }^{4}$ The characters of the Gospel of Matthew function as narrative exemplars. This article also utilizes the notion of the prototype, which has been used in vicarious dissonance studies (Cooper and Hogg 2007: 378-81). It has been noted that people experience dissonance vicariously with group members of the same degree of prototypicality: those in the core of the group identify with each other, and those on the periphery identify with each other (Cooper and Hogg 2007: 379-81). An examination of the exemplary characters of the Gospel of Matthew and their prototypical traits gives the basis for assessing the potential of vicarious dissonance aroused by the composition.

\section{Dissonance-arousing narrative characters}

The following analysis is focused on the dissonancearousing properties of certain prototypical narrative characters of the Gospel of Matthew. According to the theory of vicarious dissonance, the dissonancearousing actions of the prototypical characters will cause dissonance in the audience of the narrative. The analysis is based on a definition of cognitive dissonance as a state of arousal that occurs when a person acts responsibly to bring about an unwanted consequence. The measuring rod for deciding if a

4 On the neurological basis of the distinction, see Luomanen (2007: 217-19). 

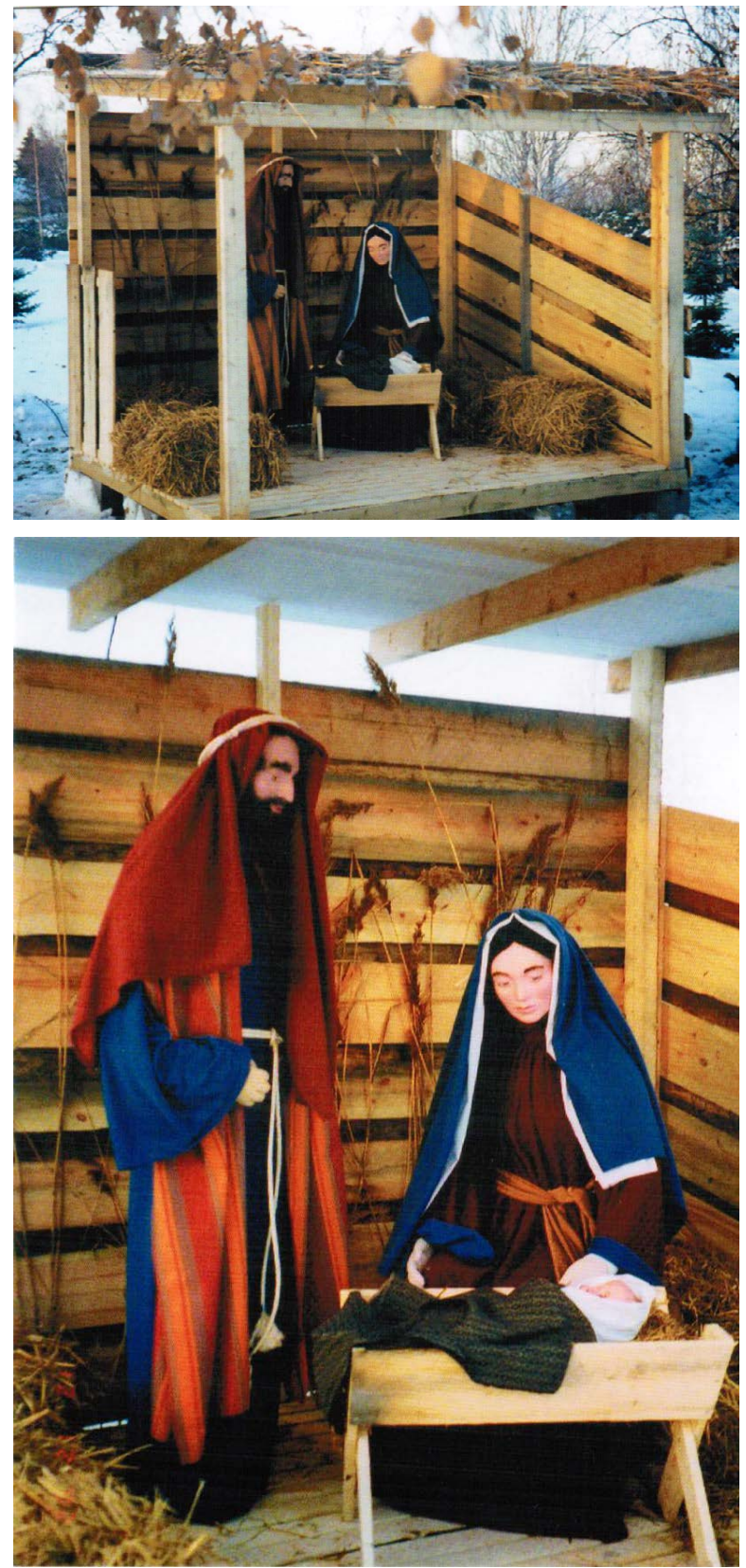

A Noel installation (2002) by Kaisa Kehus, Heli Kittilä, Aaro Leipälä, and Solveig Malinen in front of the Pyhäjoki Church. Photo: Aaro Leipälä.

consequence is undesired can be the internalized standards of one's society, culture, or family, or it can be very personal standards that have been generated by what one thinks of oneself' (Cooper 2007: 182). The analysis is divided in four parts, according to the characters in the focus. Each part begins with an examination of the prototypical features of the character in a dissonance-arousing narrative from Matthew. After that, the dissonance-arousing actions of the character will be analysed from the perspectives of responsibility and consequences of the action. In the biblical quotations, NRSV stands for New Revised Standard Version. In some cases, I have made my own translations.

\section{Joseph in the Birth Narrative}

Joseph, the father of Jesus, is the central actor in the first two chapters of the Gospel of Matthew. The narrative begins with the genealogy of Jesus, which establishes the prototypical Jewish origin of Joseph and Jesus (Matt. 1:1-17). Even though Jesus is conceived by the Holy Spirit, Joseph becomes his legitimate father $(1: 18,24-5)$. Both Jesus and Joseph are called a 'Son of David' $(1: 1,20)$. In the Gospel of Matthew, this is the title of the Messiah recognized by the crowds $(9: 27,12: 23,20: 30-1,21: 9)$ and the religious leaders $(21: 15,22: 42)$, even by a non-Jewish woman (15:22). Hence, Joseph shares the messianic title of Jesus. This title is given him by an angel of the Lord, which appears to him in a dream three times $(1: 20,2: 13,20)$. The author also calls Joseph

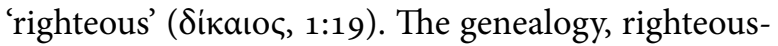
ness, and visions of Joseph make him a prototypical man from the perspective of the Jewish religion, a true descendant of the patriarchs. ${ }^{5}$ The ideology of the Gospel of Matthew is a variant of second-temple Judaism (Runesson 2016: 442-3), which is embodied in the character of Joseph. He anchors Jesus to the origins and history of the people of God.

In the birth narrative of Matthew 1-2, Joseph is mentally wrestling with the question of the unexpected pregnancy of his betrothed wife, which happened before their marital union (1:18). According to the Mosaic Law, this was a good reason for divorce (Deut. 24:1). A betrothed woman lying with another man might even have deserved the death penalty (Deut. 22:24), even though these punishments might not have been put into practice (John 8:3-11, 18:31). In Matthew 1:19, the righteous Joseph decides not to put his wife through the shame of public judgement, but to divorce her privately. There are alternative explanations for the reference to the righteousness of Joseph: either he chooses the private option despite his righteousness, or due to his righteousness. Hence, the word may refer to his love of the Mosaic Law, or to his love of Mary, or even both. The first option seems most consonant with the Matthean use of Síkaı (Hagner 2000: 18).

5 On the nightly visions of the patriarchs, see Gen. $15: 12-17,26: 24,28: 11-17,31: 10-13$. 
Joseph, being responsible for the future of his family, is preparing for the divorce. Under these circumstances an angel of the Lord appears to him (Matt. 1:20-1). The message of the Lord is twofold: First, he should not hesitate to marry Mary, since her pregnancy is caused by the Holy Spirit. Second, he should give his son the name 'Jesus', since he is the saviour of his nation. Having woken up, Joseph acts according to the vision (1:24-5). This action contains two kinds of potential for dissonance arousal. The first one is not so obvious to the authorial audience: Joseph might have questioned the authenticity of his divine vision. In this case, a later revelation of Jesus as a sinner would be the possible aversive consequence. The second potential source of dissonance arousal is more obvious: other people might put the authenticity of his vision into question. In this case, the possible aversive consequence for Joseph would be loss of the social status of a righteous man. For the authorial audience of Matthew, the action of Joseph demonstrates two rules to be applied in dissonance-arousing situations: not putting outer righteousness above the inner $(6: 1-18,23: 23-6)$, and not rejecting Jesus for the sake of conformity (10:16-39).

John and his audience in the baptism narrative

John the Baptist is the central actor in the third chapter of the Gospel of Matthew as a preacher of conversion and the baptizer of Jesus and multitudes of others. After that, his character is developed further in two narratives: In 11:1-19 there is an indirect conversation between Jesus and the captured John, who becomes the subject of Jesus' speech to the crowds. In 14:1-12, he is executed. These three sections are now examined together as a baptism narrative.

The character of John the Baptist reflects the prototype of the prophet. The proclamation of conversion is at the core of the message of the prophets of the Hebrew Bible. ${ }^{7}$ John joins the chorus and proclaims the necessity of conversion and the coming of the kingdom of heaven (Matt. 3:2). According to the author, his proclamation fulfils the prophecy of Isaiah (Matt. 3:3): 'A voice cries out: In the wilderness prepare the way of the Lord, make straight in

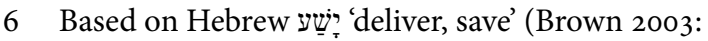
446).

7 See Isa. 1:16-20; Jer. 3:12-4:4; Ezek. 18:21-32; Hos. 14:2-10; Joel 2:12-13; Amos 5:4-6; Jonah 2:4-5; Mic. 6:8-8; Hab. 2:4; Zeph. 2:1-3; Zech. 1:3; Mal. 3:7. the desert a highway for our God' (Isa. 40:3 NRSV). Along with the prophetic proclamation, John also lives like a prophet: ascetically in the wilderness, eating locusts and honey, and dressed in camel hair and a leather belt (Matt. 3:4, 11:8). ${ }^{8}$ In his asceticism, he lives according to the teaching of Jesus: not serving wealth, but God (6:19-24). John also dies according to the teaching of Jesus: the prophets of the kingdom of God have been, and will be, persecuted and killed (5:10-12, 23:34-5). The baptism performed by John is the starting point of the public career of Jesus (3:13). Immediately after the baptism, the divine nature of the episode is confirmed by a heavenly vision and voice (3:16-17). According to Jesus, John is 'more than a prophet', fulfilling the predictions of former prophets (11:7-15).

According to Hogg, a category prototype may effectively represent the average group member, but sometimes prototypes may be extreme or polarized relative to the central tendency of a specific group. The way of perceiving or representing a social group is context-dependent, and so are the prototypes (Hogg 2008: 60). In the baptism narrative, John and Jesus represent prototypically extreme prophets. In that narrative, there are also average characters: In 3:5-6, 'Jerusalem, the whole of Judea and the whole of the surroundings of Jordan' confess their sins and are baptized by John. Later, Jesus paradoxically compares the prototypicality of John and those average persons: 'Truly I tell you, among those born of women no one has arisen greater than John the Baptist; yet the least in the kingdom of heaven is greater than he' (11:11 NRSV). Among the hearers of John, there are also characters representing the opposites of prototype (i.e. stereotypes; see Jokiranta and Luomanen 2013: 79). These Pharisees and Sadducees come to be baptized, but are not said to have confessed their sins $(3: 7)$. John calls them a 'brood of vipers' and threatens them with the wrath to come $(3: 8-10)$.

One of the actions of John has true potential for dissonance arousal: In 14:4, he is said to have expressed his disapproval to the ruler Herod Antipas, who had immorally taken the wife of his brother, Philip. There are foreseeable aversive consequences

8 His life in the wilderness resembles especially that of Eliah (1 Kings 17:2-7, 19:3-19), and the simplicity of his diet of Ezekiel (Ezek. 4:9-15). John was, however, much more properly clothed than Isaiah, who spent three years naked as a prophetic sign (Isa. 20:1-6). 
of this action chosen by John: he is captured and finally executed (14:3-11). During his imprisonment, John may have experienced cognitive dissonance, since he sends his disciples to ask Jesus (11:3 NRSV): 'Are you the one who is to come, or are we to wait for another?' Jesus gives him a dissonancereducing answer (11:4-6 NRSV): 'Go and tell John what you hear and see: the blind receive their sight, the lame walk, the lepers are cleansed, the deaf hear, the dead are raised, and the poor have good news brought to them. And blessed is anyone who takes no offence at me.' John is assured that he has been serving the truth. The authorial audience of the Gospel of Matthew is at the same time being encouraged to serve the messianic truth in dissonance-arousing situations.

The audience of John's sermons perform a collective dissonance-arousing action by confessing their sins and receiving baptism (3:6). This involves questioning their former social status and making a commitment to a new identity provided by the preaching and baptism delivered by John. The possible aversive consequence of this action is shame: What will the others think of me, when I confess my sins? And what if I have believed a false prophet? Despite the possible consequences, they confess their sins and make a commitment of faith. The authorial audience of Matthew is given examples of seeking the kingdom of God and making choices for the new identity.

\section{The audience of Jesus in the Sermon on the Mount}

The Sermon on the Mount in Matt. 5-7 is the first and the lengthiest of the five discourse sections in the Gospel of Matthew. ${ }^{9}$ According to Donald Hagner, 'The evangelist's placement of this first discourse toward the beginning of the Gospel indicates the attached importance of the material' (Hagner 2000: 82-3). This discourse of teaching is focused on the faith and life of an individual, on the person's inner and outer righteousness. Before the discourse, Jesus has called upon four disciples to follow him (4:1822) and they have wandered around Galilee. There he preaches in synagogues and heals the sick, causing big crowds to follow him (4:23-5). Seeing the crowds,

9 On the structure of Matthew and its division into sections of discourse and narrative material, see Davies and Allison (2004: 58-61). In this article, the discourse sections are seen as parts of the overall narrative.
Jesus climbs a mountain and gives his teaching. In chapters $5-7$, Jesus is the narrator and he has two narratees; the crowds and his disciples. Therefore, the audience of the Sermon of the Mount represents different prototypes. ${ }^{10}$ The difference between average and extreme prototypes is also somehow blurred, as Jesus prescribes extreme deeds (especially 5:28-30) for average persons. He also directs his words towards stereotypical characters, who remain outside the kingdom of heaven. In the parable of the two builders, Jesus expresses this heterogeneity of his audience (7:24-7).

Through the Sermon on the Mount, Jesus rhetorically connects his audience with the prototypes of the 'blessed'11 (5:3-12), the 'child of God (5:13-16)', and the 'sound builder' (7:24-25). Jesus begins his teaching by praising the blessed, who are 'poor in spirit' (5:3), 'grieving' (5:4), 'humble' (5:5), 'hungry and thirsty for justice' (5:6), 'merciful' (5:7), 'purehearted' (5:8), 'peacemakers' (5:9), and 'persecuted for the sake of righteousness' (5:10). At this point, he switches his praise from the third to the secondperson plural, and parallels his hearers with ancient prophets (Matt. 5:11-12 NRSV): 'Blessed are you when people revile you and persecute you and utter all kinds of evil against you falsely on my account. Rejoice and be glad, for your reward is great in heaven, for in the same way they persecuted the prophets who were before you.' After this, Jesus emphasizes the significance of his narratees by comparing them to the 'salt of the earth' (5:13), the 'light of the world' (5:14), a 'city built on a hill' (5:14) and a 'lamp in the house' (5:15). In 5:16, he explains the aim of these prototypical titles: the glory of the heavenly Father. Hence, he implicitly calls his narratees the 'children of God', a title he has already said applies to the peacemakers in 5:9. This title is implicitly used through the Sermon on the Mount by appealing to the relationship of the narratees with their heavenly Father $(5: 45,48 ; 6: 1,4,6$, $8-9,14,18,26,32 ; 7: 11,21)$. The authorial audience of the Sermon on the Mount is called to identify with the prototype of a child of God.

In the fifth chapter, Jesus summarizes the ethical message of the Sermon on the Mount by means of two comparisons: First, righteousness in the

10 Lauri Thurén (1990) has shown the implied audience of 1 Peter to similarly reflect mixed prototypes.

11 Makápı 'deeply happy, blessed' (Hagner 2000: 91). 


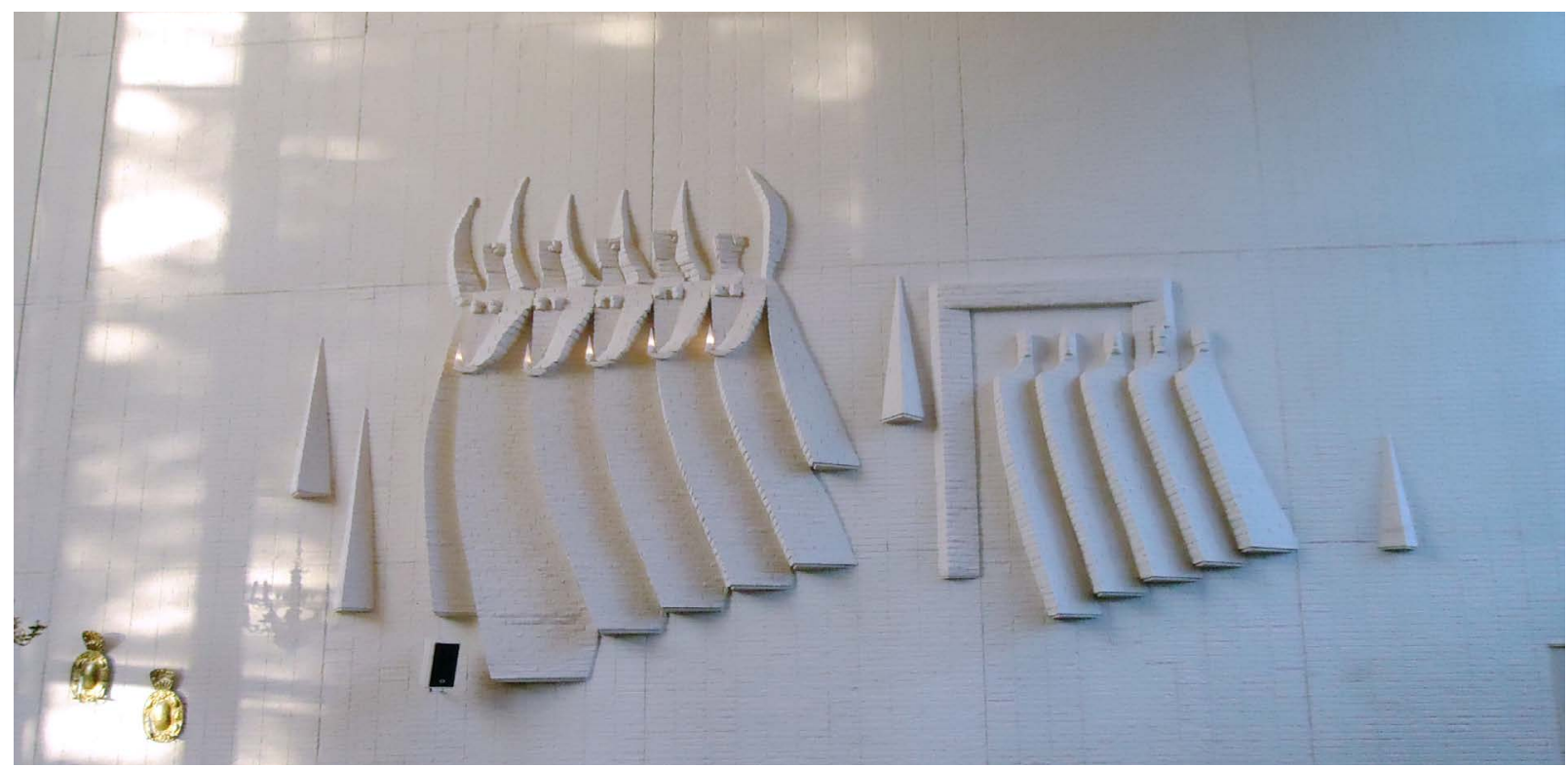

Kymmenen neitsyttä ('The Ten Virgins', 1977), a relief by Kari Juva and Väinö Korpela in the Pyhäjoki Church. Photo: Anna Karjula.

kingdom of God exceeds that of the scribes and the Pharisees (5:20). Second, his hearers should be as perfect as their heavenly Father is (5:48). In the sixth chapter, Jesus exhorts his hearers to practise piety in secret (6:1-18), to forgive others (6:14-15), and to abstain from seeking material gain (6:19-34). In the seventh chapter, Jesus forbids hypocritical judgements $(7: 1-5)$, but also uncritical acceptance of everything (7:6; Davies and Allison 2004: 674). After this, he exhorts his listeners to be active in asking for their needs from the heavenly Father $(7: 7-11)$. In addition to this, Jesus prompts action regarding the needs of others: to treat others in the way one desires to be treated oneself is the core of the Torah and prophetic scriptures $(7: 12)$. These two exhortations to take action are summed up by third, in the form of an emotionally appealing parable:

Enter through the narrow gate; for the gate is wide and the way is easy that leads to destruction, and there are many who take it. For the gate is narrow and the road is hard that leads to life, and there are few who find it. (Matt. 7:13-14 NRSV)

After this parable, Jesus warns his followers about false prophets (7:15-23). Jesus finishes his speech with the parable of two builders. The parable functions as a conclusion to the whole Sermon on the Mount in chapters $5-7$, but also echoes the exhort- ations in chapter 7 , especially verses $13-14$. The parable exhorts its hearers to take action: One who hears the words of Jesus and acts accordingly is like a wise builder, who builds his house on the rock. The one who hears the words of Jesus but does not act accordingly is like a foolish builder, who builds his house on the sand. When rain, flood, and storm come, the house of the wise man does not fall, but the house of the foolish man totally collapses (7:24-7). People admire Jesus as an original and impressive teacher $(7: 28-9)$.

To examine the dissonance-arousing elements of the Sermon on the Mount, the insistence on exercising superior righteousness $(5: 20,48)$ includes possible aversive consequences: In the temptations of sexual lust, one is advised to tear out one's eye, or tear off an arm to avoid succumbing (5:27-30). In the case of suffering abuse, one is advised to refrain from resistance (5:38-42). In 6:25-35 Jesus teaches indifference towards one's own basic needs, which is risky.

The prohibition of hypocritical judgements (7:15) may bring about dissonance-arousing situations. In such cases, the unwanted consequence of responsible action might be to find oneself in a contradictory situation with one's social environment, if there is social pressure for expressing unjust judgements. ${ }^{12}$

12 Whether this is an aversive consequence, is rather culture specific. For the authorial audience it probably was, as Cooper and Hogg (2007: 385) write: 'The self- 
The Gospel of Matthew presents Jesus with such a situation in 9:11, where the Pharisees ask his disciples: 'Why does your teacher eat with tax collectors and sinners?' The teaching of avoiding an uncritical acceptance of everything (7:6) also contains risks of social and emotional disharmony. The warning against false prophets (Matt. 7:15-23) may lead to similar problems arising when one makes choices motivated by an intention to protect that which is sacred.

The parable of two gates and two roads $(7: 13-14)$ seems to be tailored to arouse cognitive dissonance. The audience is given a choice between two options, but the broad gate and road seem to be the default. Hence, Jesus recommends his hearers to responsibly choose the narrow gate and road. The strictness of the gate and road of life indicates the likely undesired consequences of the choice. The most immediate context for the parable is an exhortation to act according to the golden rule, which sums up the law and the prophets (7:12).

The parable of the two builders $(7: 24-7)$ contains elements of cognitive dissonance arousal, but the case is not as explicit as in the instances above. The parable also presents a choice between two options, but indicates the preferability of the first by calling it 'wise', instead of by means of a straight exhortation. There are no explicit undesired consequences for building a house on the rock, although one may regard building on the rock to be more laborious. ${ }^{13}$ However, several risks associated with putting the teaching of Jesus into practice have been revealed earlier in the Sermon on the Mount. This parable calls upon the members of its audience to choose a position between ignorance of or obedience to the teachings of Jesus.

As a summary, the Sermon on a Mount contains many dissonance-arousing elements: the authorial audience is being directed to risk their social relations ( $7: 1-6,15)$, material and physical welfare (6:19$34)$, and even their organs and limbs (5:29-30). The 'golden rule' is to be active in seeing to the needs of others (7:12) also implies readiness for taking any risks for the sake of other people. ${ }^{14}$ Hence, following

concept of people in interdependent cultures is based on a joint function of the worthiness of their individual dispositions and their ability to maintain pleasant and harmonious relationships with others whom they are connected.'

13 This is explicit in the parallel text of Luke 6:48.

14 Matt. 19:16-21 provides further argumentation for this. these ethics and 'seeking the kingdom of God' (6:33) is presented as a 'narrow gate and road' (7:13-14). The rhetorical aim of the Sermon on the Mount is to persuade people to enter that gate and follow that road. For those who care for anything other than the righteousness of God, this is a dissonance-arousing call.

\section{Jesus in the Passion narrative}

The narrative of the Gospel of Matthew is built around the character of Jesus. Also the prototypes implied by the narrative are mostly defined through his words and actions. He represents the ultimate prototype of the 'messiah'. This brief analysis will not give a comprehensive picture of the prototypical and dissonance-arousing features of his character. However, a glance at these is necessary in order to form an overall picture of the prototypical and dissonance-arousing characters in the narrative. This is carried out by focusing on the most extreme element of his narrative; on his suffering and death. Only by giving the whole of his life, could he credibly set a prototype for others to be followed also in the harshest of situations.

The suffering and death of Jesus is presented in chapters 26 and 27 of the Gospel of Matthew. However, Jesus has foretold his violent arrest and death to his disciples in four narratives $(16: 21 ; 17: 12$, 22-3; 20:17-19). In the passion narrative formed by these five sections, Jesus represents the prototypes of the 'blessed' and the 'child of God' that he has set in the Sermon on the Mount. He is 'persecuted for the sake of righteousness' (5:10), and also represents the prototype of the prophet (see section 'John and his Audience in the Baptism Narrative' above). In his evening prayer before his arrest in Gethsemane (26:36-8) he 'mourns' (5:4). When arrested, he interrupts the violent resistance of his disciple, being 'merciful' (5:7) and a 'peacemaker' (5:9), 'not resisting evil' (5:39), and 'not worrying about his life or body' ( $6: 25)$. When crucified, he desperately cries out to God (27:46), that he is 'poor in spirit' 15 (5:4) and has 'hunger and thirst for righteousness' (5:6).

At two points of the passion narrative, Jesus seems to experience dissonance due to the risk of suffering and death he has foreseen and chosen. The first of these is in 16:21-3, where he reveals to his dis-

15 On the semantics of this uncommon expression, see Davies and Allison (2004: 442-5). 


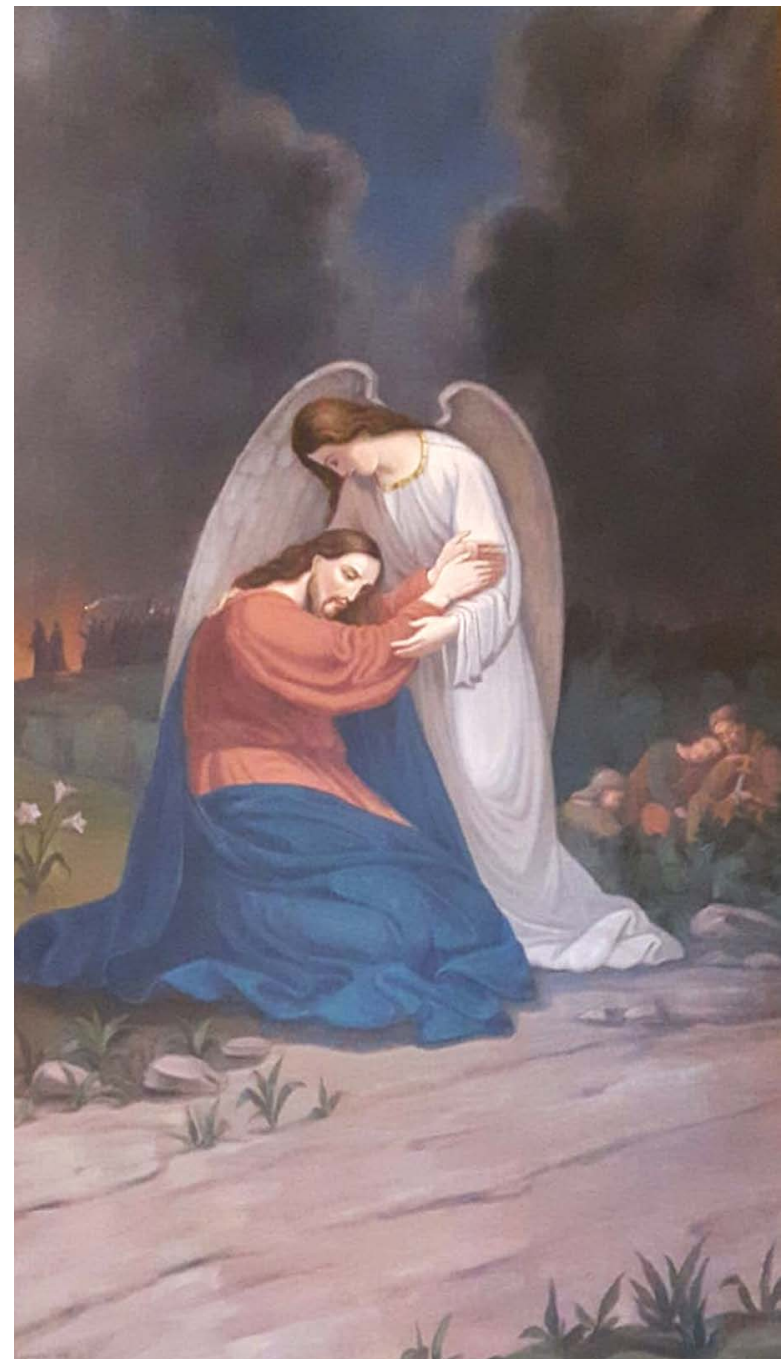

Jeesus Getsemanessa ('Jesus in Gethsemane', 1903), a painting by B. Lagerstam in the Pyhäjoki Church. Photo: Anna Karjula.

ciples that it is his duty to go to Jerusalem and suffer at the hands of the elders, high priests, and scribes. He will die and rise again on the third day. Having said this, Jesus is confronted by Peter (16:22 NRSV): 'God forbid it, Lord! This must never happen to you.' Jesus gives him a harsh answer (16:23 NRSV): 'Get behind me, Satan! You are a stumbling block to me; for you are setting your mind not on divine things but on human things.' These fierce words indicate a feeling of discomfort experienced by Jesus. He knows, also emotionally, the risks he has chosen to take.

In the evening of Gethsemane (26:36-45), Jesus is distressed and 'deeply grieved, even to death' (26:38 NRSV). He handles this extreme discomfort by praying (26:39 NRSV): 'My Father, if it is possible, let this cup pass from me; yet let not what I want but what you want be.' During the Sermon on the Mount, Jesus had taught his audience a similar prayer (6:10): 'your will be done, on earth as it is in heaven'. The prayer, which he repeats twice, has a dissonance-reducing content, as Cooper (2007: 76) writes: 'Dissonance occurs when an individual feels personally responsible for bringing about the aversive consequence ... If responsibility can be denied, the [dissonance] process is over.' In this case, the paradoxical will of Jesus is to reject his own will and share the responsibility for what happens with his Father, thus making it less personal.

At one point in the narrative, Jesus personally acts to take on the risk of a death sentence. In front of the council of scribes and elders, the high priest insists on an answer from him (26:63-4 NRSV): 'I put you under oath before the living God, tell us if you are the Messiah, the Son of God.' Jesus admits as much, and adds a prophecy: 'You have said so. But I tell you, from now on you will see the Son of Man seated at the right hand of Power and coming on the clouds of heaven.' For the high priest and the council, this is blasphemous enough to warrant a death sentence (26:65-6). Also in this situation, however, the personal responsibility of Jesus is questionable, as he is put 'under oath before the living God'. This appeal to his relational self, ${ }^{16}$ his relationship with God, restricts his personal freedom in giving an answer. Making the concept of God salient in the moment, it also facilitates the denial of responsibility uttered in the prayer offered in Gethsemane before the trial. These factors reduce, if not totally prevent, the arousal of dissonance. Jesus has already taught his disciples a similar denial of responsibility:

$$
\begin{aligned}
& \text { Beware of them, for they will hand you over to } \\
& \text { councils and flog you in their synagogues ... } \\
& \text { When they hand you over, do not worry about } \\
& \text { how you are to speak or what you are to say; for } \\
& \text { what you are to say will be given to you at that } \\
& \text { time; for it is not you who speak, but the Spirit } \\
& \text { of your Father speaking through you. (Matt. } \\
& \text { 10:17, 19-20 NRSV) }
\end{aligned}
$$

It is also worth noting that the answer Jesus gives may have been less dissonance arousing than the alternatives of falling silent or denying his messiah-

16 On different forms of the self in cognitive dissonance theory, see Cooper and Hogg (2007: 364-5).

17 See also $16: 24$ on denial of the individual self. 
ship. According to the personal standards of Jesus, denying the will of the heavenly Father or ignoring an oath before his name would most probably have been more aversive events than violent death.

As a summary, the actions of Jesus in the passion narrative are both dissonance arousing and dissonance reducing. His last journey to Jerusalem is a commitment to freely chosen action with foreseeable, extremely aversive consequences. His behaviour in the conversation with Peter and in the garden of Gethsemane indicate experiences of dissonance. He seems to reduce the dissonance by denying his personal responsibility, or at least sharing it with his heavenly Father. His self-sacrificing character offers elements for the arousal of vicarious dissonance. However, his conjunction with the character of the heavenly Father seems to facilitate responsibility denial and a consequential reduction of dissonance. ${ }^{18}$

\section{Conclusion}

The Gospel of Matthew has been shown to contain a rich assemblage of dissonance-arousing narratives. Through the characters of the narrative, the audience is given various exhortations and examples of commitments to freely chosen action with foreseeable, aversive consequences. At the same time, the audience is given exhortations and examples of giving one's own will and identity away in favour of God's will, which reduces the element of responsibility necessary for dissonance arousal. This tension between dissonance-arousing and dissonance-reducing elements should be examined further. In any case, the audience is pushed to the risky choice of following Jesus and becoming his disciple (7:13, 16:24, 28:19). Only after that, may one be comforted by the heavenly Father.

In order to arouse vicarious dissonance, a narrative has to provide characters to be identified with. This identifiability between characters and the audience is based on a shared degree of prototypicality within social categories. In the Gospel of Matthew, the overall prototype implicated by the narrative characters can be called 'child of God'. In the analysis, different varieties of this prototype were found, such as 'least in the kingdom', 'blessed' 'righteous', 'disciple,'

18 Vicarious affect has only been observed concerning voluntary choices; Cooper and Hogg (2007: 376-7). 'prophet', and 'messiah'. These vary in their degree of prototypicality in relation to the overall prototype: the first mentioned are more identifiable for an average person, whereas the last are extreme prototypes.

Attitude change is an effective way of reducing the discomfort of vicarious dissonance. As a result of this attitude change, one may identify with more extreme prototypes. As a result of identifying with more extreme prototypes, one may experience additional vicarious dissonance. I suggest this to be a feedback loop strengthening the commitment of the audience to the values promoted by the Gospel of Matthew they read and hear as a repetitive process. This suggestion may have value for understanding group commitment in general.

According to Cooper and Hogg (2007: 365), the theory of vicarious dissonance 'may have far reaching consequences for ways in which large numbers of people can be persuaded to change their attitudes and perhaps behaviors'. I hope to have given support to this suggestion in this article. For more than forty years, the theory of cognitive dissonance has been used to explain the origin of the Christian gospel. With this pioneering article, I suggest that the theory of vicarious dissonance is capable of leading us a step further, explaining the dispersal of the gospel through the Roman empire and elsewhere, noting that 'it seems to be the case that cultures in which the self is interdependent provide an especially effective context for the arousal of vicarious cognitive dissonance' (ibid. 390).

The theory of vicarious dissonance may find fruitful applications not only in biblical studies, but also in other areas of narrative and argumentative studies. The relationship between vicarious dissonance and the art of persuasion also demands further investigation. I believe cross-disciplinary perspectives to be valuable in this work, and I hope this article can be seen to be an example of this.

ThM Mikko Pisilä is an earlystage researcher in the Doctoral Programme in Social and Cultural Encounters at the University of Eastern Finland. He is studying the Gospel of Matthew as an instrument of group commitment. Pisilä is interested in the sacrificial and violent dimensions of group life and the social, cognitive, and evo-

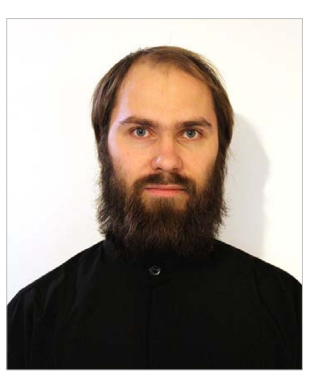
lutional dynamics behind these dimensions. 


\section{References}

Aune, David E., 2013. 'Christian beginnings and cognitive dissonance theory', Jesus, Gospel Tradition and Paul in the Context of Jewish and Greco-Roman Antiquity: Collected Essays II, Wissenschaftliche Untersuchungen zum Neuen Testament, 303 (Tübingen, Mohr Siebeck), pp. 149-81

Blackman, Shane F., Kyle T. Keller, and Joel Cooper, 2016. 'Egocentrism and vicarious dissonance', Journal of Experimental Social Psychology, 62, pp. 1-6

Brown, Francis, 2003. The Brown-Driver-Briggs Hebrew and English Lexicon: With an Appendix Containing the Biblical Aramaic (Peabody, Hendrickson Publishers)

Brown, Jeannine K., 2002. The Disciples in Narrative Perspective: The Portrayal and Function of the Matthean Disciples (Atlanta, Society of Biblical Literature)

Cabrido, John Aranda, 2010. A Portrayal of Jesus in the Gospel of Matthew: A Narrative-Critical and Theological Study (Lewiston, Edwin Mellen Press)

Carter, Warren, 2001. Matthew and Empire: Initial Explorations (Harrisburg, Trinity Press)

- -2015. 'Narrative readings, contextualized readers, and Matthew's Gospel', The Oxford Handbook of Biblical Narrative, ed. Danna Noland Fewell (Oxford University Press), pp. 1-17

Chatman, Seymour, 1979. Story and Discourse: Narrative Structure in Fiction and Film (Ithaca, Cornell University Press)

Combrink, H. J. Bernard, 2006. 'The challenge of overflowing righteousness: to learn to live the story of the Gospel of Matthew', Identity, Ethics, and Ethos in the New Testament, ed. Jan G. van der Watt, Beihefte zur Zeitschrift für die neutestamentlich Wissenschaft und die Kunde der älteren Kirche, 141 (Berlin, Walter de Gruyter), pp. 23-48

Cooper, Joel, 2007. Cognitive Dissonance: Fifty Years of a Classic Theory (London, SAGE Publications)

Cooper, Joel, and Michael A. Hogg, 2007. 'Feeling the anguish of others: a theory of vicarious dissonance', Advances in Experimental Social Psychology, 39, pp. 359-403

_-2014. 'Dissonance arousal and the collective self: vicarious experience of dissonance based on shared group membership', The Social Self: Cognitive, Interpersonal and Intergroup Perspectives, ed. Joseph P. Forgas and Kipling D. Williams (Hoboken, Taylor and Francis), pp. 327-41

Davies, W. D., and Dale C. Allison, 2004. A Critical and Exegetical Commentary on the Gospel According to Saint Matthew in Three Volumes. Vol. I: Introduction and Commentary on Matthew I-VII, The International Critical Commentary on the Holy Scriptures of the Old and New Testaments (London, T\&T Clark)

Festinger, Leon, 1957. A Theory of Cognitive Dissonance (Stanford University Press)

Festinger, Leon, Henry W. Riecken, and Stanley Schachter, 1956. When Prophecy Fails (Minneapolis, University of Minnesota Press)
Gager, John G., 1975. Kingdom and Community: The Social World of Early Christianity (Englewood Cliffs, Prentice-Hall)

Hagner, Donald A., 200o. Matthew 1-13, Word Biblical Commentary, 33A (Grand Rapids, Zondervan)

Harmon-Jones, Eddie, and Judson Mills (eds.), 1999. Cognitive Dissonance: Progress on a Pivotal Theory in Social Psychology (Washington DC, American Psychological Association)

Hogg, Michael A., 2008. 'Social categorization, depersonalization, and group behavior', Blackwell Handbook of Social Psychology: Group Processes, ed. Michael A. Hogg and Scott Tindale (Hoboken, John Wiley \& Sons), pp. 56-85

Jokiranta, Jutta, and Petri Luomanen, 2013. 'Sosiaalisen identiteetin näkökulma', Johdatus sosiaalitieteelliseen raamatuntutkimukseen, ed. Petri Luomanen, Jutta Jokiranta and Outi Lehtipuu, Suomen Eksegeettisen Seuran Julkaisuja, 105 (Helsinki, Suomen Eksegeettinen Seura), pp. 67-84

Levine, Amy-Jill, and Marc Zvi Brettler (eds.), 2011. The Jewish Annotated New Testament: New Revised Standard Version (Oxford University Press)

Liddell, Henry George, and Robert Scott, 1996. A GreekEnglish Lexicon: With a Revised Supplement (Oxford University Press)

Luomanen, Petri, 2007. 'The sociology of knowledge, the social identity approach and the cognitive study of religion', Explaining Christian Origins and Early Judaism: Contributions from Cognitive and Social Science, ed. Petri Luomanen, Ilkka Pyysiäinen and Risto Uro, Biblical Interpretation Series, 89 (Leiden, Brill), pp. 199-229

Nestle, Erwin, and Eberhard Nestle, 2008. Novum Testamentum Graece et Latine. Editio XXVII, eds. Barbara Aland, Kurt Aland, Johannes Karavidopoulos, Carlo M. Martini and Bruce M. Metzger (Stuttgart, Deutsche Bibelgesellschaft)

Norton, Michael I., Benoît Monin, Joel Cooper, and Michael A. Hogg, 2003. 'Vicarious dissonance: attitude change from the inconsistency of others', Journal of Personality and Social Psychology, 85(1), pp. 47-62

Powell, Mark Allan, 1990. What Is Narrative Criticism? (Minneapolis, Fortress Press)

Runesson, Anders, 2016. Divine Wrath and Salvation in Matthew: The Narrative World of the First Gospel (Minneapolis, Fortress Press)

Smith, Eliot R., and Michael A. Zárate, 1992. 'Exemplar based model of social judgment', Psychological Review, 99(1), pp. 3-21

Tajfel, Henri, 1981. Human Groups and Social Categories (Cambridge University Press)

Taylor, Nicholas H., 1998. 'Cognitive dissonance and early Christianity: a theory and its application reconsidered', Religion and Theology, 5(2), pp. 138-53

Thurén, Lauri, 1990. The Rhetorical Strategy of 1 Peter: With Special Regard to Ambiguous Expressions (Turku, Åbo Akademis förlag) 